\title{
Propolis: biochemical and clinical evaluation
}

\author{
Maryam Hani Abduljalal* , Omar Mohammed Yaya*, Maher Abdul Satar Ibrahim* \\ , Imad A Thanoon** \\ *Department of Biochemistry, College of Medicine, University of Mosul , ${ }^{*}$ Department of \\ Pharmacology, College of Medicine , University of Mosul , Mosul , Iraq \\ Correspondence: omermohammed@uomosul.edu.iq
}

(Ann Coll Med Mosul 2021; 43 (2):216-219).

Received: $7^{\text {th }}$ Dece. 2021; Accepted: $22^{\text {th }}$ Dece. 2021.

\section{ABSTRACT}

Propolis is a glue-like substance which produced by honey bees, it is related to honey. It is also called bee glue as they use it to reconstruct their hives and for the hives maintenance. They make propolis by mixing many substances like bee wax, saliva, exudate collected from trees, sap flows and other sources.

Many studies have made concerning importance of propolis and it is wide medical benefits as it is role in improving immunity, reducing elevated blood pressure, curing many allergic conditions and dermatological diseases.

The aim of this review is to enumerate some of its chemical constitutions and it is role in treating some medical conditions.

Keywords : propolis, bee glue, honey and bees .

$$
\begin{aligned}
& \text { تقيم سريري و بايوكيميائي لعكبر النحل }
\end{aligned}
$$

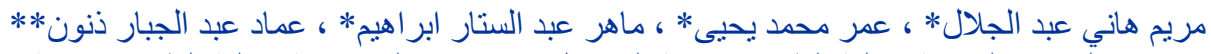

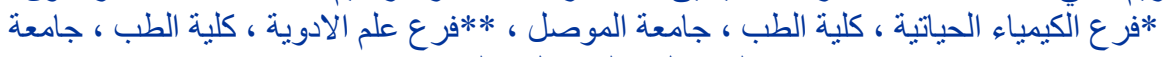

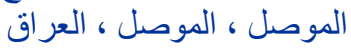

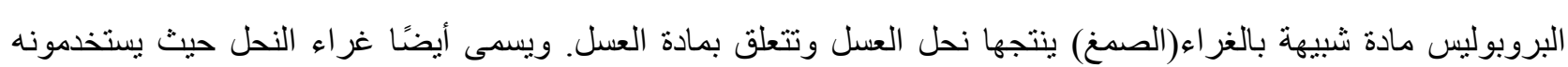

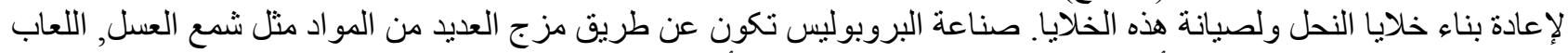

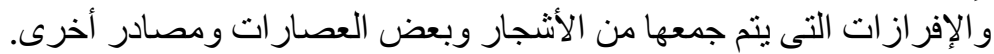

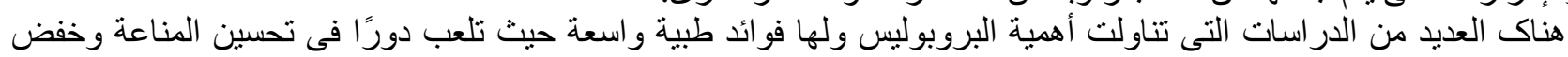
ضغط الدم المرتفع و علاج العديد من أمر اض الحسات الهبة البروبة الأمر واض الجلدية.

الكلمات المفتاحية : العكبر ، صمغ النحل ، العسل و النحل .

\section{INTRODUCTION}

oney bees made many beneficial materials in their hives starting from honey, bee wax, bee bread and propolis that have a clear role in curing many diseases. Honey is a complex substance that made of nectar, stored in the honey comb.

Bee wax, used to build the walls of the comb. Like honey, beeswax has many uses such as candle manufacturing, soap, cosmetic products and many pharmaceutical benefits.

Bee bread are made by Worker bees, they make bee bread by mixing pollen, glandular secretions and honey, after a fermentation to be allowed, bee bread is prepared. This fermentation process will release from the pollens, additional nutrients containing antibiotics and fatty acids so it has many medical uses too. ${ }^{1,2}$

\section{Propolis}

Is a resinous substance collected by honeybees from different sources to seal the unwanted opening in their hives. Despite propolis may cause allergic reaction for many peoples, it have a lot of medical implementation like cold syrups and flu remedies ${ }^{3-5}$. 


\section{Medical uses of the propolis 1-Antioxidant effect:}

Many studies show that propolis and its related derivatives seem to eliminate oxidative stress specially in radiation causes injury to the brain, by increasing the activities of antioxidant enzyme and reducing the lipid peroxidation formation and also by decreasing the generation of free radical. ${ }^{3-6}$

\section{2- Anti-inflammatory effect:}

Propolis exerts a clear anti-inflammatory activity which seems to be due to its constituents like "phenolic acids" and their esters, flavonoid, "steroids" and some "amino acids". this antiinflammatory activity of propolis may related to ${ }^{7,8}$.

(1) Its ability to inhibit the cyclooxygenase (COX) enzyme thus consequently inhibit the biosynthesis of prostaglandin

(2) Reducing free radical generation as discussed above.

(3) "nitric oxide (NO) synthesis" inhibition.

(4) Its ability to reduce the concentration of the inflammatory cytokines.

(5) Propolis has an immunosuppressive activity.

\section{3- Cardiovascular system protection and} reducing the atherosclerosis:

Propolis protective characteristics is will reported by many researchers which came from it is antioxidant mechanism.

The polyphenols in the propolis interact with the "nitric oxide (NO)" generation from the endothelium of the vascular system, which leads not only to vasodilatation but also to increase the expression of the genes that protect the vascular system.

\section{4- Propolis as Antimicrobial agent:}

All propolis types appear to have an antimicrobial activity as some of it is constituents appear to inactivate certain kinds of bacteria and reducing its multiplications ability by preventing bacterial divisions and even cause cytoplasmic dysfunction.

Examples of the pathogens that propolis affects are Enterococcus faecalis, Helicobacter pylori Escherichia coli, Neisseria gonorrhoeae, Listeria monocytogenes, Staphylococcus epidermidis, Streptococcus pyogenes, Staphylococcus aureus and even Vancomycin-resistant Enterococcus faecium. "The flavonoid" components of propolis are associated with its activity as antibacterial. .11,12

Propolis also express an antiviral activity, by inhibiting the integration of the viral genetic material with DNA of the host thus inhibit the replication of the virus as in HIV and hepatitis $C$ viruses.

More over propolis show a significant activity in the treatment of herpes which caused by herpes simplex viruses for both oral herpes caused by herpes simplex virus type 1 and genital herpes caused by herpes simples type 2, a sexually transmitted disease resulting in painful blisters on the genitalia ${ }^{11}$.

A research done to compare the effect of honey and propolis in treating herpes with acyclovir, an antiviral medication, for several trails. In a 4 of these trails, out of 6 , propolis was more effective than acyclovir in the treatment of herpes mainly cold sores.

There are many commercial products for propolis as antimicrobial has produced as toothpaste, oral sprays and lozenges. ${ }^{13}$

\section{5- Propolis and COVID-19:}

There are many studies which have proven that propolis shows antiviral activity for many types of viruses like rhinoviruses, respiratory syncytial virus and influenza (flu), also Propolis seems to booster the immune system effectively. ${ }^{14}$

For those reasons, many researchers adopted the idea of using propolis in treating patients infected with SARS-CoV-2 (it is corona virus that causes COVID-19) or even to prevent the infection with this virus. ${ }^{15-17}$

\section{6- Propolis and dermatological applications:}

Propolis has been proved as stimulant for the skin tissues growth and for the regeneration and modulation of the collagen. Burns and wounds treated with propolis were found to have lower concentrations of free radicals so Propolis treatment improve the cell viability and collagen production thus improve wound healing. It is also used in many creams and lotions that treat patients with dermatitis. The advertising avenue taken by some of skin products that claims a "calming, moisture rich, anti-ageing" propolis effects. ${ }^{18-20}$

\section{7-Hepatocellular protective characteristic of propolis:}

Propolis healing effect on the liver cells were studied by many researchers, they clarify that propolis reduce the hepatotoxicity in studied laboratory mice induced by chemical substances like acetaminophen. Moreover, propolis were used as traditional remedies in some autoimmune disease, diabetes mellitus, cancers and neurological problems like Alzheimer and define curing effect are on studies. ${ }^{2,21-23}$

\section{Chemical components of the propolis}

When a chemical extraction for propolis performed using different types of solvents, different components were founded, the most important elements were the flavonoids, resins, waxes, balsams/balms, pollen, aromatic oils, organic materials and terpenoids (table 1) ${ }^{10}$ 
Chemical components of the propolis (table 1) ${ }^{10}$

\begin{tabular}{|c|c|}
\hline $\begin{array}{l}\text { Chemical } \\
\text { groups }\end{array}$ & Compounds \\
\hline "Alcohols" & $\begin{array}{l}\text { "Benzyl alcohol, cinnamyl alcohol", } \\
\text { 2-methyl-2-propen-1-ol, } \\
\text { hydroquinone, 2-phenylethanol, a- } \\
\text { glycerol phosphate, glycerol, }\end{array}$ \\
\hline Aldehydes & $\begin{array}{l}\text { Benzaldehyde, hexanal, phenolic } \\
\text { aldehyde, isovanillin, 4- } \\
\text { hydroxybenzaldehyde }\end{array}$ \\
\hline $\begin{array}{l}\text { Aliphatic } \\
\text { acids and } \\
\text { aliphatic } \\
\text { esters }\end{array}$ & $\begin{array}{l}\text { Ethanoic acid, (2Z)-2-Methylbut-2- } \\
\text { enoic acid, Butanoic acid, (2E)-But- } \\
\text { 2-enoic acid, (2E)-But-2-enedioic } \\
\text { acid, 2-Methylpropanoic acid, 2- } \\
\text { Methylbutanoic acid, 2-Methylpropyl } \\
\text { acetate, 3-Methylbutyl acetate }\end{array}$ \\
\hline $\begin{array}{l}\text { "Amino } \\
\text { acids" }\end{array}$ & $\begin{array}{l}\text { "Alanine", tyrosine, valine, " } \beta \text { - } \\
\text { alanine", tryptophan, " } \alpha \text {-aminobutyric } \\
\text { acid", threonine, " } \gamma \text {-aminobutyric } \\
\text { acid", serine, "arginine", proline, } \\
\text { "asparagine", phenylalanine, } \\
\text { "aspartic acid", ornithine, "cysteine", } \\
\text { methionine, "glutamic acid", lysine, } \\
\text { glycine, leucine, "histidine, } \\
\text { isoleucine". }\end{array}$ \\
\hline $\begin{array}{l}\text { Aromatic } \\
\text { acid }\end{array}$ & $\begin{array}{l}\text { Benzenecarboxylic acid, "3,4- } \\
\text { Dihydroxy-trans-cinnamate”, (2E)-3- } \\
\text { Phenylprop-2-enoic acid, 4- } \\
\text { Hydroxycinnamic acid, "(2E)-3-(4- } \\
\text { hydroxy-3-methoxyphenyl)prop-2- } \\
\text { enoic acid", 3,4,5-Trihydroxybenzoic } \\
\text { acid, 2,5-Dihydroxybenzoic acid, 4- } \\
\text { Hydroxybenzoic acid, (E)-3-(3-- } \\
\text { hydroxy-4-methoxyphenyl)prop-2- } \\
\text { enoic acid, 4-Methoxycinnamic acid, } \\
\text { 2-Hydroxybenzoic acid, 4-Hydroxy- } \\
\text { 3-methoxybenzoic acid }\end{array}$ \\
\hline $\begin{array}{l}\text { Aromatic } \\
\text { esters }\end{array}$ & $\begin{array}{l}\text { Benzyl acetate, benzoic acid } \\
\text { phenylmethyl ester, benzyl }(E)-3- \\
\text { (3,4-dihydroxyphenyl)prop-2-enoate, } \\
\text { benzyl coumarate, benzyl (E)-3-(4- } \\
\text { hydroxy-3-methoxyphenyl)prop-2- } \\
\text { enoate, benzyl isoferulate, Benzyl 2- } \\
\text { hydroxybenzoate, butenylcaffeate, 3- } \\
\text { Phenyl-2-propenyl benzoate, } \\
\text { cinnamylcaffeate, ethyl benzoate }\end{array}$ \\
\hline Chalcones & $\begin{array}{l}\text { Dihydroxymethoxychalcone, } \\
\text { sakuranetinchakcone, 2',4,4',6'- } \\
\text { Tetrahydroxychalcone, } \\
\text { pinobanksinchalcone, } \\
\text { pinocembrinchalcone }\end{array}$ \\
\hline Flavanones & $\begin{array}{l}\text { Pinobanksin, naringenin, } \\
\text { "Pinobanksin,-3-butyrate, } \\
\text { Pinobanksin-3- acetate,Pinobanksin } \\
\text {-3- methyl ether". }\end{array}$ \\
\hline Waxy acids & $\begin{array}{l}\text { Arachnid acid, cerotic acid, linoleic } \\
\text { acide, montanic acid, behenic acid, }\end{array}$ \\
\hline
\end{tabular}

\section{CONCLUSION}

Ancient people have considered propolis as a traditional medicine since the year $300 \mathrm{BC}$, namely ancient Egyptians used it to cure many diseases, more over in the World War II doctors were use propolis to enhance wound healing.24

During the last decade uses of propolis become very popular referred to it is properties as antibacterial, antifungal, antiviral, antiprotozoal, and antiinflammatory.

Many diseases are under intensive studies such as COVID-19 infection and the raising hope of using propolis as a line for treatment patient infected with corona viruses, also, for many other autoimmune disease, diabetes mellitus, liver disease, cardiovascular diseases cancers and neurological problems like Alzheimer. ${ }^{9,26}$

So propolis can be considered as a raising hope to cure many diseases.

\section{REFERENCES}

1.Cornara, L.; Biagi, M.; Xiao, J.; Burlando, B. Therapeutic properties of bioactive compounds from different honeybee products. Front. Pharmacol.2017, 8, 412.

2.Eteraf-Oskouei, T.; Najafi, M. Traditional and Modern Uses of Natural Honey in Human Diseases: A Review. Iran. J. Basic Med. Sci. 2013, 16, 731-742.

3.Cao, X.P.; Chen, Y.F.; Zhang, J.L.; You, M.M.; Wang, K.; Hu, F.L. Mechanisms underlying the wound healing potential of propolis based on its in vitro antioxidant activity. Phytomedicine 2017, 34, 76-84.

4.Ali, A.M.; Kunugi, H. Bee honey protects astrocytes against oxidative stress: A preliminary in vitro investigation. Neuropsychopharmacol. Rep. 2019, 39, 312-314.

5. Khalaf DA, Thanoon I A.J . Effects of bee propolis on blood pressure record and certain Biochemical Parameters in healthy volunteers . Ann coll Med Mosul 2018;40(1):20-26

6. Kocot, J.; Kielczykowska, M.; Luchowska-Kocot, D.; Kurzepa, J.; Musik, I. Antioxidant Potential of Propolis, Bee Pollen, andRoyal Jelly: Possible Medical Application. Oxid. Med. Cell. Longev.2018, 2018, 7074209.

7.Araujo, M.A.; Libério, S.A.; Guerra, R.N.; Ribeiro, M.N.S.; Nascimento, F.R. Mechanisms of action underlyingthe anti-inflammatory and immune modulatory effects of propolis: A brief review. Rev. Bras. Farmacogn. 2012, 22, 208-219.

8.Paulino, N.; Abreu, S.R.; Uto, Y.; Koyama, D.; Nagasawa, H.; Hori, H.; Dirsch, V.M.; Vollmar, A.M.; Scremin, A.; Bretz, W.A.Anti-inflammatory effects of a bioavailable compound, Artepillin C, in Brazilian propolis. Eur. J. Pharmacol. 2008, 587, 296-301 
9.Daleprane, J.B.; da Silva Freitas, V.; Pacheco, A.; Rudnicki, M.; Faine, L.A.; Dörr, F.A.; Ikegaki, M.; Salazar, L.A.;Ong, T.P.; Abdalla, D.S.P. Antiatherogenic and anti-angiogenic activities of polyphenols from propolis. J.Nutr.Biochem. 2012, 23, 557-566.

10. Anjum, S.I.; Ullah, A.; Khan, K.A.; Attaullah, M.; Khan, H.; Ali, H.; Bashir, M.A.; Tahir, M.; Ansari, M.J.; Ghramh, H.A. Composition and functional properties of propolis (bee glue): A review. Saudi J. Biol. Sci.2018.

11. Kwon, M.J.; Shin, H.M.; Perumalsamy, H.; Wang, X.; Ahn, Y.-J. Antiviral effects and possible mechanisms of action of constituents from Brazilian propolis and related compounds. J. Apic. Res. 2020, 59, 413-425.

12. Lan, X.; Wang, W.; Li, Q.; Wang, J. The Natural Flavonoid Pinocembrin: Molecular Targets and PotentialTherapeutic Applications. Mol. Neurobiol. 2016, 53, 1794-1801

13. Ristivojevi'c, P.; Trifkovi'c, J.; Andri'c, F.; Milojkovi'c-Opsenica, D. Poplar-type propolis: Chemical composition, botanical origin and biological activity. Nat. Prod. Commun. 2015, 10, 1869-1876 Cornara, L.; Biagi, M.; Xiao, J.; Burlando, B. Therapeutic properties of bioactive compounds from differenthoneybee products. Front. Pharmacol.2017, 8, 412.

14. Shaha, A.; Mizuguchi, H.; Kitamura, Y.; Fujino, H.; Yabumoto, M.; Takeda, N.; Fukui, H. Effect of Royal Jelly and Brazilian Green Propolis on the Signaling for Histamine $\mathrm{H} 1$ Receptor and Interleukin-9 Gene Expressions Responsible for the Pathogenesis of the Allergic Rhinitis. Biol. Pharm. Bull. 2018, 41, 1440-1447.

15. Guo, Y.R.; Cao, Q.D.; Hong, Z.S.; Tan, Y.Y.; Chen, S.D.; Jin, H.J.; Tan, K.S.; Wang, D.Y.; Yan, Y. The origin, transmission and clinical therapies on corona virus disease 2019 (COVID19) outbreak-An update on the status. Mil. Med. Res. 2020, 7, 1-10.

16. da Silva, F.M.; da Silva, K.P.; de Oliveira, L.P.; Costa, E.V.; Koolen, H.H.; Pinheiro, M.L.; de Souza, A.Q.; de Souza, A.D. Flavonoid glycosides and their putative human metabolites as potential inhibitors of the SARS-CoV-2 main protease (Mpro) and RNA-dependent RNA polymerase (RdRp). Mem. Inst. Oswaldo Cruz 2020, 115, e200207

17. Hashem, H. IN Silico Approach of Some Selected Honey Constituents as SARS-CoV-2 Main Protease (COVID-19) Inhibitors. EJMO 2020, 4, 96-200.

18. Olczyk, P.; Wisowski, G.; Komosinska-Vassev, K.; Stojko, J.; Klimek, K.; Olczyk, M.; Kozma, E.M. Propolis modifies collagen types I and Illccumulation in the matrix of burnt tissue.
Evid.Based Complement.Altern. Med. 2013, 2013, 423809.

19. Farooqui, T.; A Farooqui, A. Molecular mechanism underlying the therapeutic activities of propolis: Acritical review. Curr.Nutr. Food Sci. 2010, 6, 186-199.

20. Ali, A.M.; Kunugi, H. Apitherapy for Parkinson's disease: A focus on the effects of propolis and royal jelly. Oxid. Med. Cell. Longev.2020, 2020, 1727142.

21. Ali, A.M.; Kunugi, $H$. Royal jelly as an intelligent anti-aging-A focus on cognitive aging and Alzheimer's disease: A review. Antioxidants 2020, 9, 937.

22. Rao, P.V.; Krishnan, K.T.; Salleh, N.; Gan, S.H. Biological and therapeutic effects of honey produced by honey bees and stinglessbees: A comparative review. Rev. Bras. Farmacogn. 2016, 26, 657-664. [CrossRef]

23. Salatino, A.; Fernandes-Silva, C.C.; Righi, A.A.; Salatino, M.L. Propolis research and the chemistry of plant products. Nat. Prod. Rep. 2011, 28, 925-936.

24. Ahmad, R.S.; Hussain, M.B.; Saeed, F.; Waheed, M.; Tufail, T. Phytochemistry, metabolism, and ethnomedical scenario of honey: A concurrent review. Int. J. Food Prop. 2017, 20, S254-S269.

25. Farooqui, T.; Farooqui, A.A. Beneficial effects of propolis on human health and neurological diseases. Front. Biosci. 2012, 4, 779-793.

26. Sahlan, M.; Irdiani, R.; Flamandita, D.; Aditama, R.; Alfarraj, S.; Ansari, M.J.; Khayrani, A.C.; Pratami, D.K.; Lischer, K. Molecularinteraction analysis of Sulawesi propolis compounds with SARS-CoV-2 main protease as eliminary study for COVID-19 drug discovery. J. King Saud Univ. Sci. 2021, 33, 101234. 